UDC 531. $46: 669.14 .018 .295: 621.882 .6: 539.42 .13$

摩擦接合用高力ボルトの

\title{
遅れ破壊強度に及葟す形状の影響
}

斉藤誠*

\section{Effect of Shapes on the Delayed Fracture Strength of High Strength Friction Grip Bolts}

\section{Makoto Saito}

Synopsis

As one of trial improvement of delayed fracture strength of high strength friction grip bolt, the mitigation of stress concentration of each part of bolt was carried out and there obtained-the following results.

(1) By cutting off incomplete thread up to effective diameter, the delayed fracture life can be extended.

(2) The fine thread with bigger area of core section is more excellent than the coarse thread, but the effect is small in large diameter.

(3) The delayed fracture strength is better if the thread root radius is larger.

(4) Larger radius of head-to-shank fillet is desirable.

(5) The usage of self-aligning nut is effective for the mitigation of the bending stress which grows in tightening and the said usage extends the delayed fracture life.

\section{1.はし がき}

摩摖接合用高力ボルトは，高強度化の要求はあるが F13T級の高力ボルトで崌れ破壊による折損が生じた Table 1. Positions of occurrence of delayed fracture observed in F13T high strength bolts.

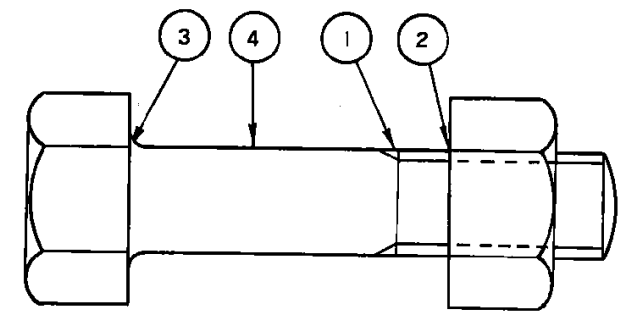

\begin{tabular}{|c|c|c|c|c|c|}
\hline $\begin{array}{c}\text { Position of } \\
\text { fracture }\end{array}$ & $\begin{array}{c}1 \\
\text { Incomplete } \\
\text { thread }\end{array}$ & $\begin{array}{c}\text { (2) } \\
\text { Complete } \\
\text { thread }\end{array}$ & Fillet & Shank & Total \\
\hline $\begin{array}{c}\text { Number of } \\
\text { fructured } \\
\text { bolts }\end{array}$ & 66 & 24 & 5 & 6 & 101 \\
\hline Ratio & 65.3 & 23.8 & 5.0 & 5.7 & $100 \%$ \\
\hline
\end{tabular}

ため，現在F11T級までの使用にとどまっている。し かし橋梁に使われる鉿板はますます高強度化する傾向 にあり，F13T 䄲以上の遅れ破壊的に安定な高力ボル トの出現か望まれている。この要求に答えるため各方 面でボルト材啠の開発が鋭意進められてい る。一方，遅れ破壊を起した約 100 本のF13 Tボルトをその折損部位別に分離してみるとTable 1 の如くになり，安部1) が指摘しているよ 5 に，応力集 中の大きい(1)不完全ねじ部，および(2)ナットのかかり 始めの第 1 ねじ山などか破壤発生の大半を占めてい る。表中で応力集中のない(4)シャンク部から折損して いるものも6本あるが，これらは表面の孔食からクラ ックが発生したすのと考它られ，応力集中が原因にな っているとみなされる。このよ5に折損が応 力集中部に多いのは遅れ破壊現象が応力集中 の程度に依存するためであり2),3)，この点度 労破壊と相通ずるところがある。ボルトの遅 れ破罱の場合には降伏点に近い応力で締付ら れるためねひじ谷底で一部塑性降伏が起って いる可能性があるが, 㝿労の場合には塑生変形を伴な わない低応力の繰返状態で論じられるので，両者を同
昭和 46 年 12 月 5 日受付

* 大同製銓蛛研究開発本部 中央研究所 
Table 2. Chemical composition of material used.

\begin{tabular}{c|c|c|c|c|c|c|c|c}
\hline $\mathrm{C}$ & $\mathrm{Si}$ & $\mathrm{Mn}$ & $\mathrm{P}$ & $\mathrm{S}$ & $\mathrm{Cu}$ & $\mathrm{Ni}$ & $\mathrm{Cr}$ & $\mathrm{Ti}$ \\
\hline 0.21 & 0.75 & 1.20 & 0.013 & 0.020 & 0.13 & 0.11 & 1.50 & 0.08 \\
\hline
\end{tabular}

Table 3. Mechanical properties of material used.

\begin{tabular}{c|c|c|c|c}
\hline $\begin{array}{c}0.2 \% \text { Proof } \\
\text { stress }\end{array}$ & Tensile stress & Elongation & $\begin{array}{l}\text { Reduction of } \\
\text { area }\end{array}$ & Hardness $\mathrm{H}_{\mathrm{R}} \mathrm{C}$ \\
\hline $123.7 \mathrm{~kg} / \mathrm{mm}^{2}$ & $154.7 \mathrm{~kg} / \mathrm{mm}^{2}$ & $14.0 \%$ & $53.2 \%$ & 44.2 \\
\hline
\end{tabular}

Heat treatment : $850^{\circ} \mathrm{C}$ Oil quenched

$300^{\circ} \mathrm{C}$ Tempered

一視して取扱 万わけにはゆかない。しかし応力集中の 緩和といら面からみれば，ボルトの㝿労強度の改善に 用いられているいくつかの方法が利用できるのではな いかと思われる。このような観点にたってボルトの応 力集中の和が遅れ破壞強度に及汪す影響を調べたの でその結果について報告する。

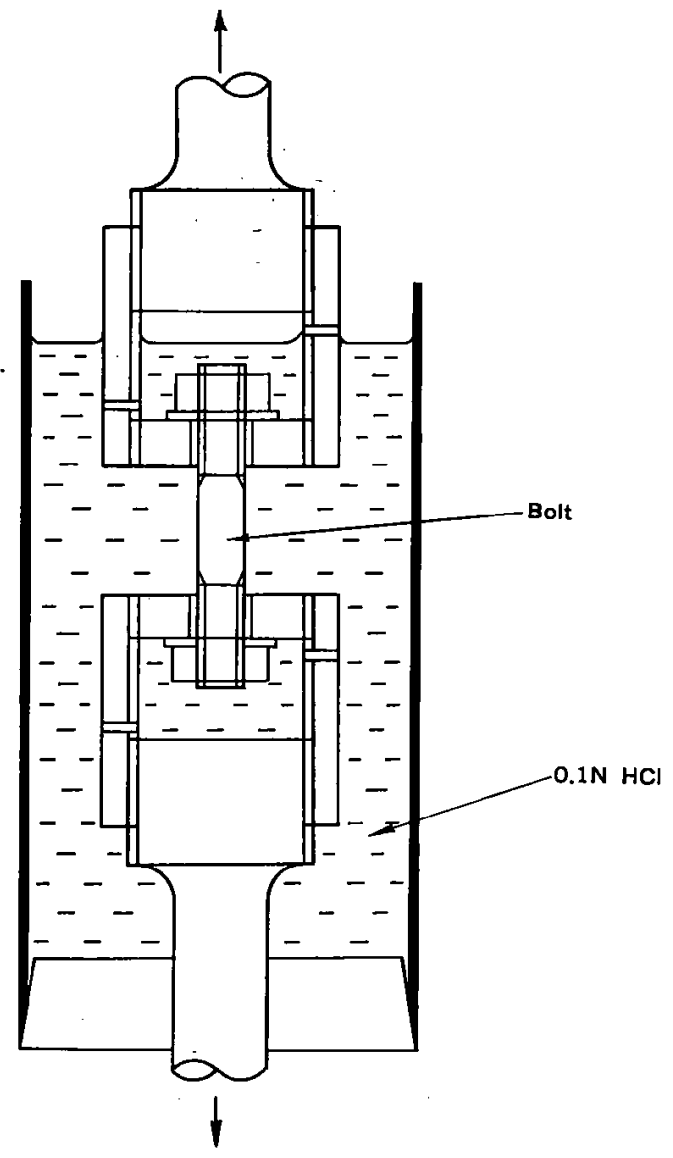

Fig. 1. Sketch of testing apparatus.

\section{2. 供試材お゙び試倹方法}

供試材としては, Table 2 に示すよ 5 な低炭素 $\mathrm{S}_{\mathbf{1}}$ $-\mathrm{Mn}-\mathrm{Cr}$ 鋼を用い, 形状変更の勃果をはっきりさせ るため比較的遅れ破買感受性の高い状態として，引張 強さ約 $155 \mathrm{~kg} / \mathrm{mm}^{2}$ に熱処理したものを用いた。その 機械的性質を Table 3 に示す。

Fig. 1 に示すよ5な試験装置に試験片を盖し， $0.1 \mathrm{~N}-\mathrm{HCl}$ 水溶液中で引張荷重を負荷し破断までの 時間を測定した。引張装置としてはレバー型の 4 ton および50ton 容量のものを用いた。

\section{3. 实 験 結 果}

\section{1 ねじ切上り部の形状}

Table 1 からもわかるよ $5 に$ ね ねじ切上りの不完全 ねじ部が一番迤れ破壊的に弱い。これは転造ねじであ っても不完全ねじ部には Photo. 1 に示すよ 5 な鋭い 切欠が生じ，この高い応力集中が原因で遅れ破壊クラ ックが発生するためと考えられる。不完全的じ部に生 じるこのよ5な鋭い切欠は，ブランクの絞り方と転造 ダイスの端面形状を工夫することによってなかなりの 程度まで鈍化することがでさるが，本実験では耐疲労 用ボルトでよく层用されている移行溝の効果に着目 し，遅れ破壊強度に対するその効果を検討してみた。

\section{1. 1 試 酫 片}

試験片は, Fig. 2 (A)に示すよ5な両端 $55 \mathrm{~mm}$ に

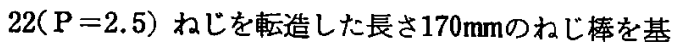
本型とし，この不完全ねじ部を，(B)有效径，(C)谷底径 $\left(\mathrm{d}_{1}\right)$, および(D) アンダーカット $\left(0.96 \mathrm{~d}_{1}\right)$ の 3 種類 の潹さに削り込んで移行溝を形成したものである。試 験片の形状をそれでれ Fig. 2(A)〜（D)に示す。 移行清の巾はねじの乎び径の半分の $11 \mathrm{~mm}$ に一定とし また溝のフィレット半径は，形状 (B)，(C) およぴ (D) についてそれぞれ 0.8，1.4，および $1.8 \mathrm{~mm}$ とした。 

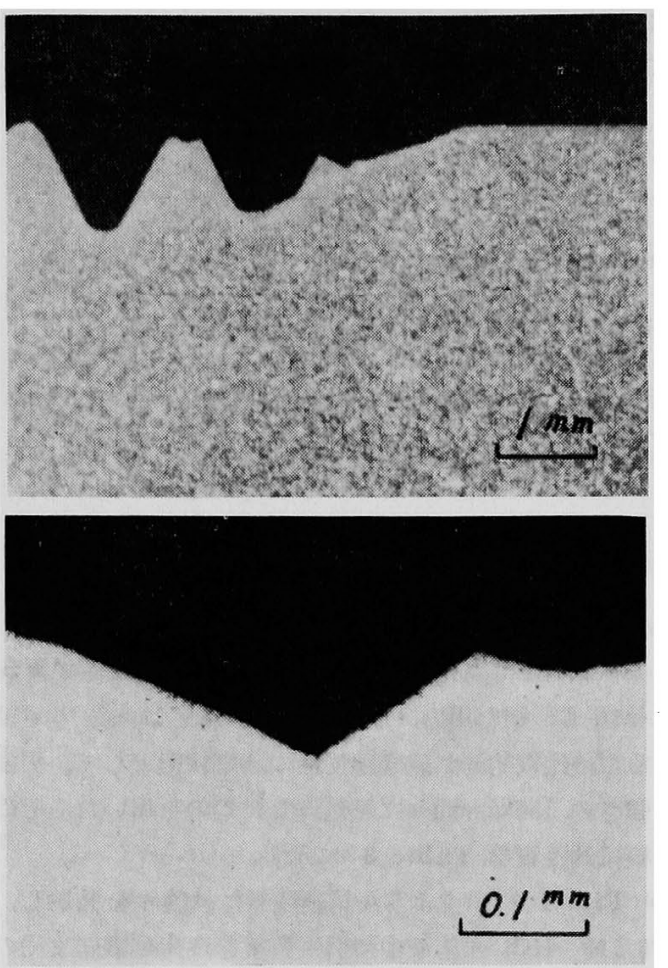

Photo. 1. A sharp notch observed at the incomplete thread.(M22, F11T)

試験片はすべて Fig. 2 の形状に加工後熱好理し た。

\section{1. 2 实 硂 結 果}

$0.1 \mathrm{~N} \mathrm{HCI}$ 水溶液中での各形状の試酮片の䐅 れ破 壞寿命を Table 4 K示与。基本形のボルトA型にた いし，不完全ねじ部を有効径まで削込んだB型は寿命 が50\%程度長くなっており移行清の効果が認められ る。移行溝を谷底径あるいはマンダーカットに深く削 込んたCあるいはD型も，改善の効果はあるがB型よ り劣っている。応力集中の緩和の点からはCあるいは

Table 4. Effect of the transfer groove shapes on the delayed fracture life.

\begin{tabular}{|c|c|c|c|c|}
\hline \multirow[b]{2}{*}{ Series } & \multirow{2}{*}{$\begin{array}{l}\text { Shape of transfer } \\
\text { groove }\end{array}$} & \multirow{2}{*}{$\begin{array}{l}\text { Ultimate } \\
\text { strength } \\
\text { of bolts }\end{array}$} & \multicolumn{2}{|c|}{ Fracture life } \\
\hline & & & $\begin{array}{r}\text { ton } \\
\mathrm{P}=30\end{array}$ & $\mathrm{P}=20$ \\
\hline A & Conventional type & 46. 1ton & $6.1 \mathrm{hr}$ & $11.0 \mathrm{hr}$ \\
\hline B & $\begin{array}{l}\text { Cut off to effec- } \\
\text { tive diameter }\end{array}$ & 46.0 & 10.35 & 18.7 \\
\hline $\mathrm{C}$ & $\begin{array}{l}\text { Cut off to minor } \\
\text { diameter }\left(d_{1}\right)\end{array}$ & 45.8 & 9.9 & 13.3 \\
\hline $\mathrm{D}$ & Cut off to $0.96 \mathrm{~d}_{1}$ & 45.3 & 8.2 & 14.8 \\
\hline
\end{tabular}

P : applied load
(A) Normal type
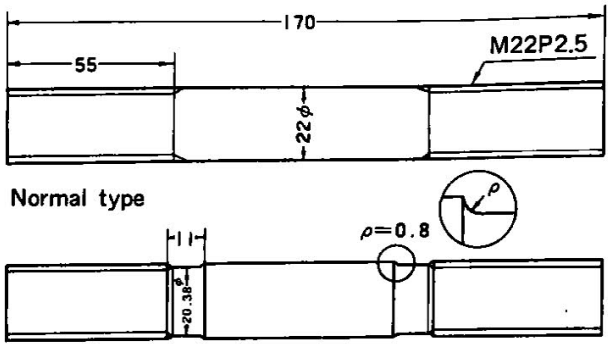

(B) Cut off to effective diameter

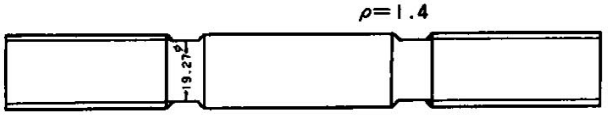

(C) Cut off to minor diameter $\left(d_{1}\right)$

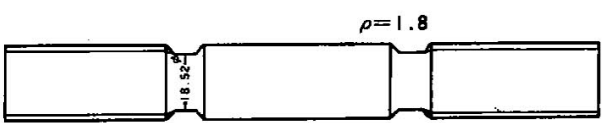

(D) Cut off to $0.96 d_{1}$

Fig. 2. Shapes of transferred grooves.

D型の方が有利であるが，移行溝を深くすると断面積 が減少するため応力が増加し，応力集中の緩和效果が 相殺されてしまうためと考えられる。

Photo. 2 に破断したボルトの外観を示すが， A型 は不完全ねじ部から破断しているのにたいし，B型で は完全ねじ部から破断しており移行溝による不完全ね じ部改良の効果か現われている。C型は移行湮から完 全ねじ部一移るフィレットから，またD型は移行淟か らシャンク部へ移るフイレットからそれぞれ破断して いる。

以上の結果から，有効径程度の樑さまで移行清を入 れることは遅れ破壊寿命を延ばすのに有效であること がわかった。これは移行满によって不完全ねじ部の応 力集中が緩和されるためと考えられる。移行淟を深く すると断面積か減じ，導入力を一定とした場合，引張 忘力が増して遅れ破䏅寿命の増加の程度が減ずる。ま た実用上にはボルトの締付けトルクによ って，㨭り応力が増加する点にも注意を 要する。

3. 2 ピッチおよびねじ谷底半影の

細目ねじが並目ねじに比べて疲労強度 が優れていることは衆知のことであり， また高力ボルトにおいて細目ねじを使え ば高い締付力を許容できるとい5報告が ありむ)，細目ねじは並目わじに比べて優 れている点が多い。細目れじは同一呼び 径の並目ねじに比へて有効断面積が大き いことねねじ瑇を一つのクラックと考爯 


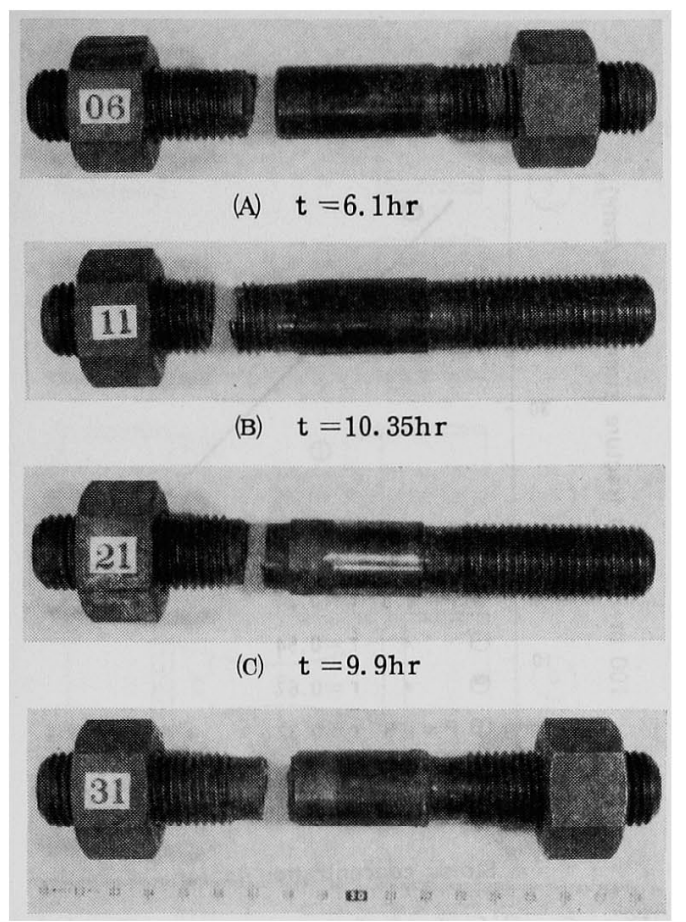

(D) $\mathrm{t}=8.2 \mathrm{hr}$

Photo. 2. Fracture positions of tested bolts in $0.1 \mathrm{~N}-\mathrm{HCl}$ (Load=30ton)

れば細目ねじの方がクラックの長さが短いことにな ク,クラックの伝播に対しても有利になると考えられ る。

ねじ谷底半径については, やはり疲労強度の面から 多くの文献が谷底半径の大きい方か優れているとして おり, 円孤ねじ，75\%ねじ5)，（r=0.180P, $r$ : 谷底 半径，P：ねじビッキ)などが提案あるいは規格化さ れており，さらにベリリゥムのよ 5 に切欠感受性の高 い材料では55\%ねじ（r=0.267P）が有効であること も報告されている6)。このよ5なピッチや谷底半径の 影響について幄れ破壊の面から検討された例がみあた らないので, 疲学強度におけるのと同様な効果が期待 できるか否かを㭘討してみた。

\section{2. 1 試 的合}

ピッチの影響の榆討は，M 6 ねじ棒（ピッチ0.5お よび $1.0 \mathrm{~mm}$ ) ならびにM22ねじ棒（ピッキ1.5および $2.5 \mathrm{~mm})$ の 2 種類の寸法で行なった。

谷底半径の影響をみるため，Photo. 3 に示す形状 のねじ山を M22 ねじ棒に加工して央験に供した。A 型は改正前の J I S の比較的谷底半径の鋭いもの，B 型は新 J I S 型 (1965年改訂, 谷底半径の規定が外さ れているが谷底径が大きなっているので必然的に谷 底半径が大くなる), C 型は Stripping strength

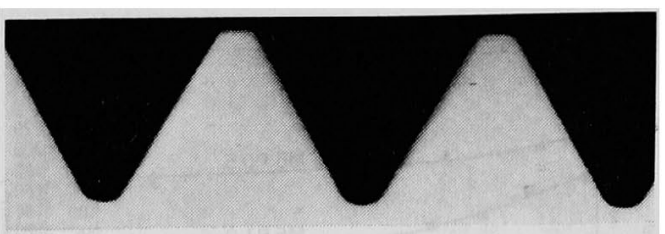

(A) $\mathrm{p}=2.5 \quad \mathrm{r}=0.24$
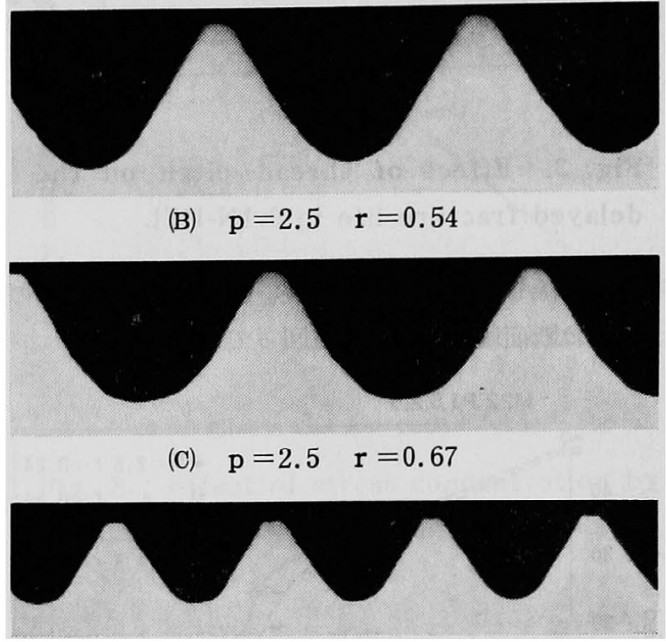

(D) $\mathrm{p}=1.5 \quad \mathrm{r}=0.32$

Photo. 3. Profiles of threads (M22)

が低下しない限界のねじ山の強度をとった $55 \%$ ねじで ある。D型はねじ山形状をB型と相似にし，ビッチの みを $1.5 \mathrm{~mm}$ と細目にしたものである。各ねじの寸法 を Table 5に示す。

Table 5. Dimension of test threads.

\begin{tabular}{l|r|r|r|r}
\hline $\begin{array}{c}\text { Basic } \\
\text { size }\end{array}$ & $\begin{array}{c}\text { Pitch } \\
\mathrm{mm}\end{array}$ & $\begin{array}{c}\text { Minor dia } \\
\mathrm{mm}\end{array}$ & $\begin{array}{c}\text { Root radius } \\
\mathrm{mm}\end{array}$ & $\mathrm{Kt}^{*}$ \\
\hline \multirow{3}{*}{ M 6} & 0.5 & 5.46 & 0.054 & 3.51 \\
\hline & 1.0 & 4.92 & 0.108 & 3.51 \\
\hline \multirow{3}{*}{ M22 } & 2.5 & 18.75 & 0.24 & 3.50 \\
\hline & 2.5 & 19.29 & 0.54 & 2.78 \\
\hline & 2.5 & 19.55 & 0.67 & 2.61 \\
\hline & 1.5 & 20.38 & 0.32 & 2.91 \\
\hline
\end{tabular}

* Kt : by Neuber (for multiple notches)

3. 2. 2 実 験 結 果

Fig. 3 に6 ねじ棒の遅孔破壊曲線を示す。図に みられるよ5に並目ねじに比して細目ねじの強度は明 らかに高く，100時間で破断しない限界の荷重（以下 遅れ破壊限界荷重とよぶ）を比較すると70\%高い値と なっている。M6 細目ねじの谷底断面積は並目ねじの それに比へ 31\% 大きいが，谷底断面積で遅れ破壞限 


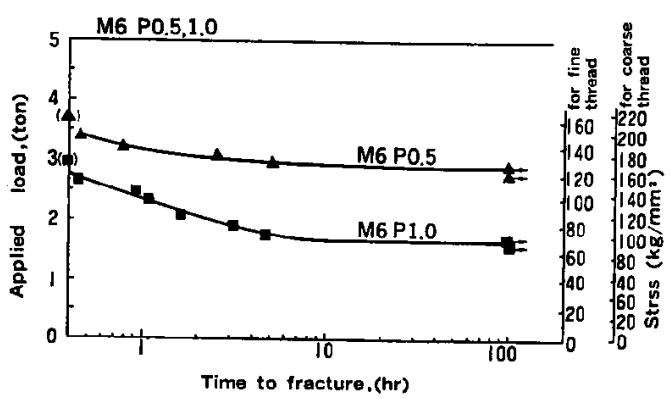

Fig. 3. Effect of thread pitch on the delayed fracture life in $0.1 \mathrm{~N}-\mathrm{HCl}$.

界荷重を除した值（以下遅れ破壤限界応力とよふ）の 上梨率は断面積の増加率を上回っている。

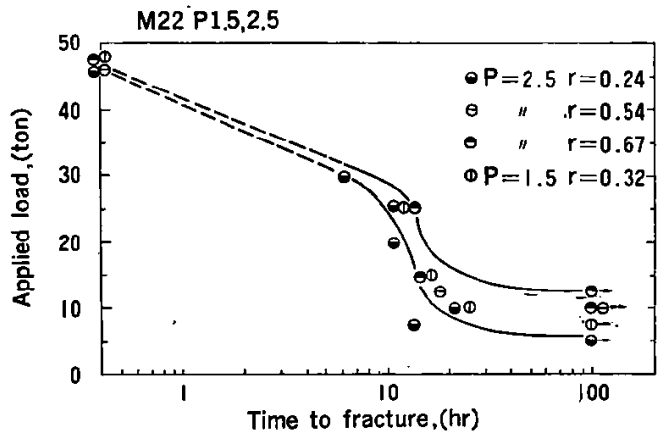

Fig. 4. Effect of pitch and root radius on the delayed fracture life in $0.1 \mathrm{~N}-\mathrm{HCl}$.

Fig. 4 は M22 ねじ棒の遅れ破壊曲線を示す。負 荷々重が高く曲線の勾配が急なところではネジ山形状 による遅え破壊君命の差異は明瞭ではないが，低荷重 域では谷底半径の大きなるの活ど優れており，限界荷 重にははっきりした差が認められる。Fig. 5 はねじ 谷底の応力集中係数（Neuberの多重切欠で近似）に 对する遅れ破買限界応力をブロットしたものである が，明らかに応力集中の小さなねじ山形状のものは遅 れ破㙏限界応力が高い。D型の細目ねじのものは， $\mathrm{A}, \mathrm{B}, \mathrm{C}$ の 3 つの並目ねじの遅れ破壊限界応力に上べ て低い值となっており，M6の小径ねじで得られたよ 万な強度上开効果は現われておらず, むしろ谷底断面 積増加の初果を下回っている。

以上の結果から，わじ山形状，特に谷底半径の影響 が大きく, 谷底半徍の大きいもの活ど遅れ破壤強度は 優れているといえる。ビッキを細かくする効果が，ボ ルト小径と大径ボルトとで逆な結果となったが，この 原因については明らかでない。

\section{3 首下半往の影䇺}

橋析の下フランジではボルトの頭が方になるよ 5

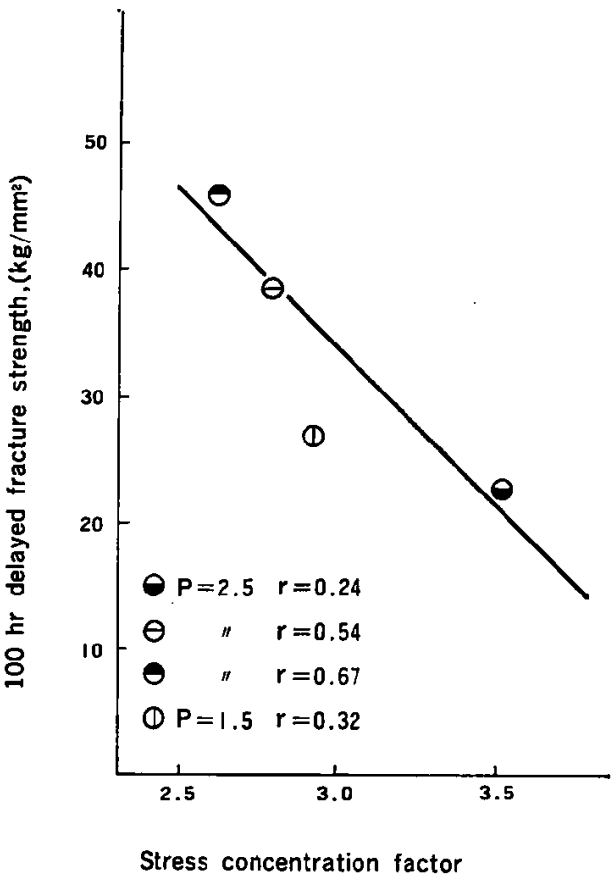

Fig. 5. Effect of stress concentration by thread root radius on the delayed fracture strength.

に締付られるので首下に水分がたまりやすく首トビが 生じやすいといわれる7)。低強度の炭素鋼ボルトに比 べ熱好理された合金鎆ボルトは首下半径を大きくしな ければならないことは疲労強度の面です強調されてい るが，応力集中の楥和の点からみると，これが痋机破 壊強度の改善にも役に立つであろうことは容易に類推 できる。そこで首下の応力集中度と遅机破纍強度との 関係をみるため次のような実験を行なった。

\section{3. 1 試糇}

首下半径の影響をみるためには実体ボルトの首下半 径をいろいろ変化させて試験するのが望ましいが，座 金を介して引張るため首下への液のまわりが覀く実験 の完全が期し難い。そこで Fig. 6 に示す小型の段付 丸棒試験片をもって代用した。図中の(1),(2),(3)の試験

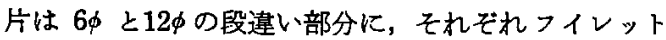
半径 $(\rho) 0.25 ， 0.6$ および $1.7 \mathrm{~mm}$ の丸味を付けた。 ので, この5ち (2) $\rho=0.6 \mathrm{~mm}$ のめのはJ I S 摩擦接 合用ボルトの首下の応力集中度（䄪 2.0）合せための である。(4)（51はフイレット半径を $0.6 \mathrm{~mm}$ に周定し 肩の直径を $7.2 \mathrm{~mm} \phi$ および $18 \mathrm{~mm} \phi$ に変点応力集中度 を変化させたものである。は応力集中の小さい条件 を得るため，特に半径を $10 \mathrm{~mm}$ と大きくしテーパー接 続したもので応力集中係数は 1.13 である。 


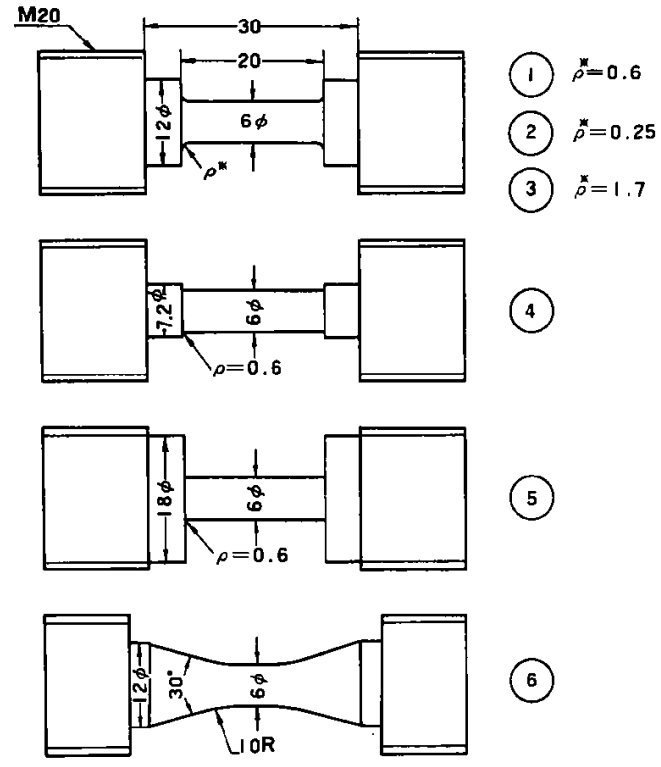

Fig. 6, Test specimen with shoulder fillet.

試験片の両端に切った M20 のれじ部をチャックに ねじ込み，Fig. 1 に示寸装置に組込んで $0.1 \mathrm{~N}-\mathrm{HCl}$ 水溶液中に浸清し破断までの時間を測定した。

\section{3. 2 実 䀦 結 果}

Fig. 7 飞各段付丸棒の $0.1 \mathrm{~N}-\mathrm{HCl}$ 水溶液中での

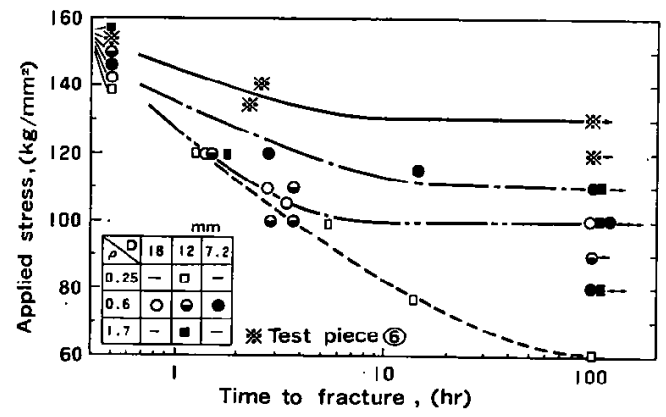

Fig. 7. S-T curves of the test specimen with various shoulder fillet radii in $0.1 \mathrm{~N}$ -HCl.

遅れ破壊曲線を示す。フイレット半径の大きいものほ ど高い強度を示しており，またフイレット半径が一定 の場合には平行部と肩部の直径差の小さいもの洼ど遅 れ破壊強度は高い。各形状の応力集中保数を横軸に， $100 \mathrm{hr}$ 掘れ破壤限界応力を縱軸にとって整理した結果 が Fig. 8 である。図にみられるように応力集中保数 にたいして比較的良い直線関係を示して扰り，応力集 中係数の小さいるのほど高い強度を示している。

遅机破燷強度に及济す応力集中の影響についての Troiano ${ }^{2)}$ 等, 山本・藤田 3 の報告でもやはり忘力集

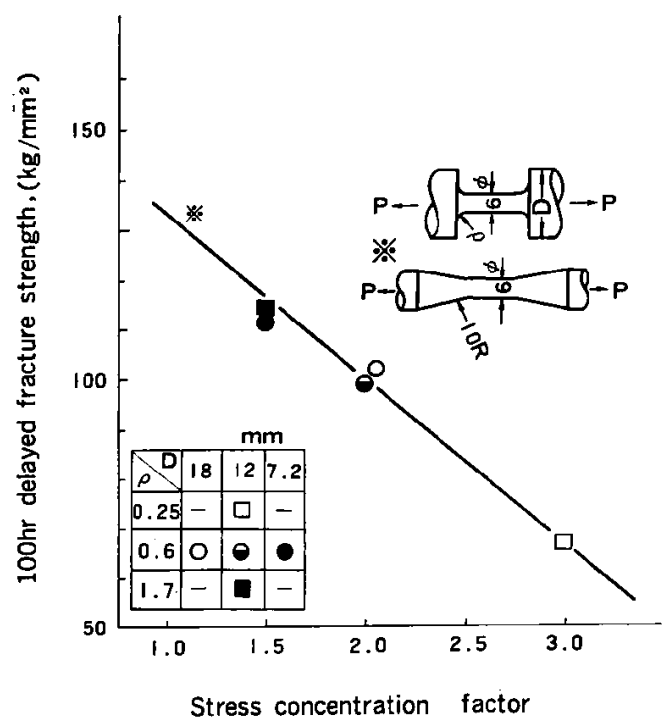

Fig. 8. Effect of stress concentration by shoulder fillet radius on the delayed fracture strength.

中の高いものは遅れ破㯖強度が低下すると論じている が，彼等の実験では比較的遅机破壤を促進する環境の 作用が弱くかつ材料の延性が高い場合には，いわゆる 切欠強化が生しるため応力集中係数 $1 \sim 4$ の範囲でむ しろ平滑丸棒より高い遅机破猿強度を示しており当実 験結果と相異している。これは，当実験に使用した材 料が遅れ破壊感受性の高い材料であり，かつ㻮境の遅 机破滾促進作用も $0.1 \mathrm{~N}-\mathrm{HCl}$ と荷酷なた切切強化 が起らず応力集中か増すとともに単調に遅れ破燷強度 が低下したためと考えられる。ボルト首下について考 点てみても，機械加工に上って生じる鋭い瘷が形状的 な応力集中と重って 2 重切欠を形成しきわめて高い応 力集中を引起すことは容易に想像されるので，首下半 径を大きくし応力集中を低く抑えることは遅れ破壊強 度の向上に有効なことといえる。

\section{4 球面座金の効果}

ボルトの締付施行にあたっては，ボルト穴の食違 い，鋼板の段違い，曲りなどのために，ボルトが板に たいして直角に締付られす，首下面あるいはナット下 面が板に対してある角度をりって締付られることが少 なくない。またボルト自身の曲り，ボルトの首下面お よびナット座面の軸心にたいする傾きなどもこれらの 傾向を助長し局部的な応力の上昇をもたらす。特に摩 擦接合用ホルトは太く短いので締付によって大きな曲 げ応力を生じやすく，これが断面曲げ剛性の小さなね じ部に集中し，この部分の折損率を更に高愿因と なっていると思われる。 
板の表面とナット座面との傾斜を解消するには，球 面坐ナットとワッシャーの組合せが有効と考えられ る。ジグ用六角ナット（J I S B5226）には球面座 付きナットが制定されてており，R． Ollis ${ }^{8)}$ あ表面の くさび角による導入力の低下扰よび疲労寿命の低下か： 球面座ナットの採用によって著しく楥和されることを 紹介している。また英国では橋梁用ボルトとして，球 面座ナットとワッシャーの組合せ，および首下座面の 球面化したものなどが一部使われており，その効果が 期待できるものと思われる。そこで以下表面くさび角 に対する球面座金の効果を検討してみた。

\section{4. 1 試碒片および試験方法}

試験に用いたボルトは, 市販の WT/8”の F11T ボ ルトで枋質は S CM3 である。これに Fig. 9 に示

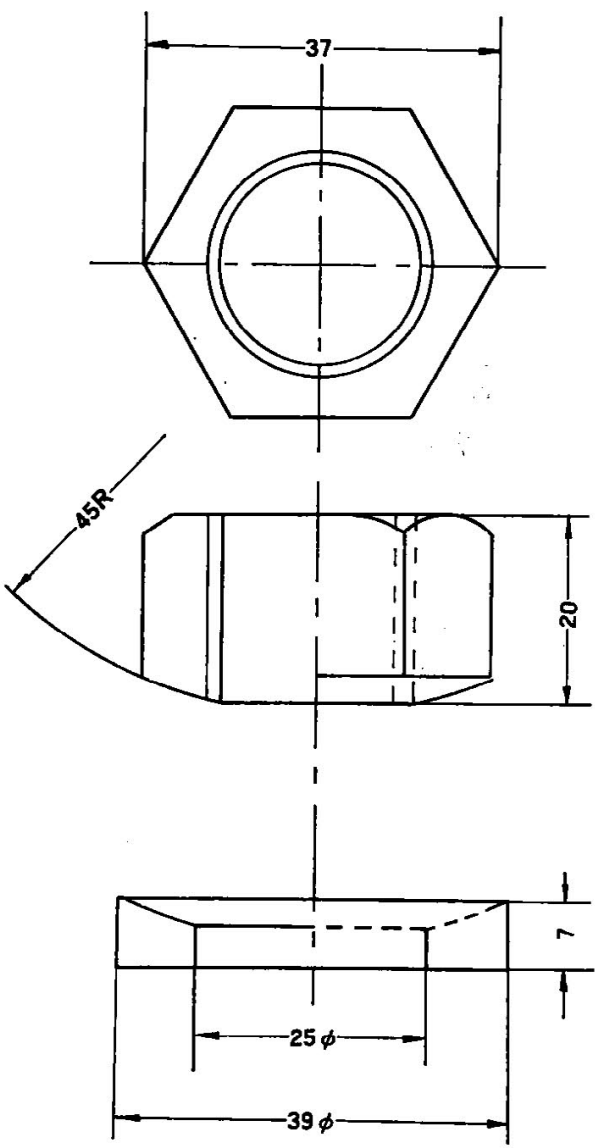

Fig. 9. Self-aligning nut and washer. (for $\mathrm{w}^{\mathrm{T}} / \mathrm{g}^{\prime \prime}$ )

す球形の球面座ナット・ワッジーを組合せ実験に供 した。また比較のため通常の六角ナット・平ワッシャ 一の組合せも同装実験した。

遅れ破壊試験としては Fig.10に示す寸法の䋨付体
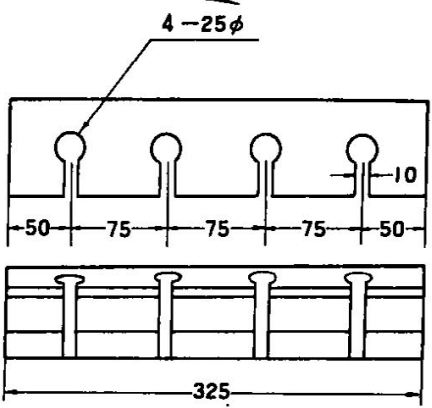

$\theta=0,2,4,8^{\circ}$

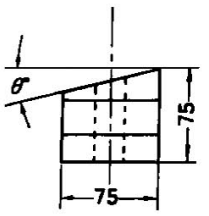

Fig. 10. Plain and wedged plates for testing the conventional and self-aligning nuts.

にボルトを 21tonの標準導入力で締付けた後，0.1N -HCl 水溶液を入れた液槽に浸漬し破断までの時間を 測定した。液は $24 \mathrm{hr}$ 毎に新しいものを入換えた。編 付状況を Photo. 4 と示す。

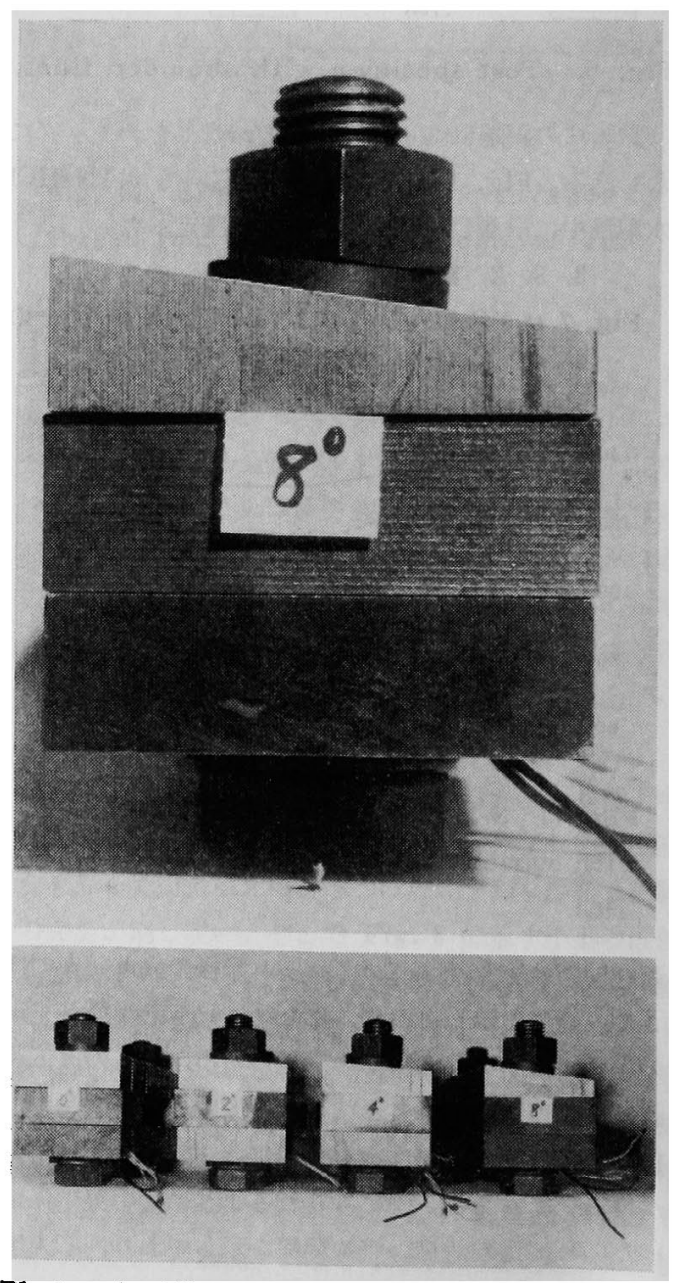

Photo. 4. Photographs of bolts tightened to various wedge angle plate with selfaligning nuts. 

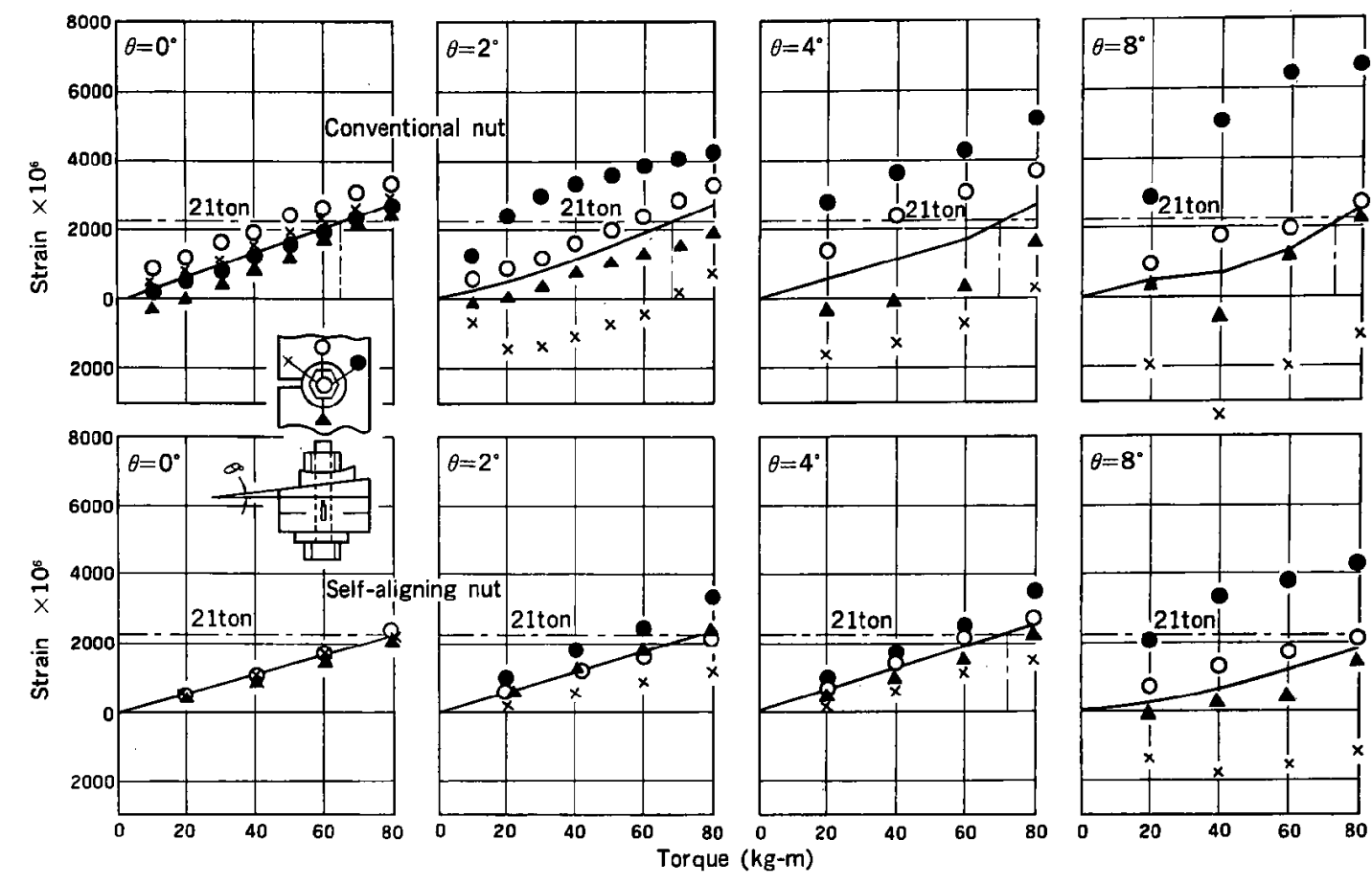

Fig. 11. Torque-strain curves of bolts tightened with conventional and self-aligning nuts.

遅れ破壊試験にさきだちボルトの軸部に 4 枚の塑性 歪ゲージを貼付け，楴付トルクと各ゲージの歪量との 関係を求めるとともに，4枚のゲージの算術平均雪を 基準に所要締付トルクを求めた。

\section{4. 2 実 跧 果}

Fig.11に一般ナットと球面座ナットの $0^{\circ}, 2^{\circ}, 4^{\circ}, 8^{\circ}$ 各くさび板に締付けた場合の軸昰を示す。一般ナット では板のくさび角が増すにつれて著しく 4 つの軸歪間 に差違を生じ大きな曲げが発生しているのがわかる。 これにたいし球面座ナットを用いた場合は一般ナット に比べて著しく曲げが憈和されている。なおくさび角 $8^{\circ}$ のむのは球面坐の効果が失われている結果にな っているがここれはさび角が $8^{\circ}$ にるなると座金の 内面とボルト表面が接触し，球面座では追随できなく なってくるためである（遅れ破罗試験の場合には座金 の内面を削り取って実験した)一般ナットを使ってく

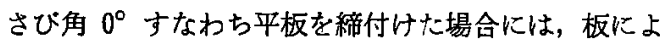
る曲げが生じないため本来 4 枚のゲージの歪は同大で なければならないが，図にみられるように相当量の違 いが生じている。これは前述したよ5にボルト自体の 曲げおよび首下座面の傾きに起因しているものと考兄 られる。球面座ナットを使った場合には平板締付の場 合にも㖉は 4 枚ともに良く揃っており，ボルト自体に 原因する曲げの楥和にも有効であることが 5 かが る。
Fig.12に一般ナットと球面座ナットの $0.1 \mathrm{~N}-\mathrm{HC}_{1}$ 中での遅れ破罗寿命を示す。嵞軸か破断時間，横軸が くさび角である。一般ナットを使って締付けたるの

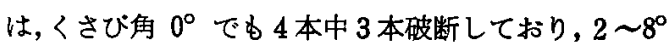

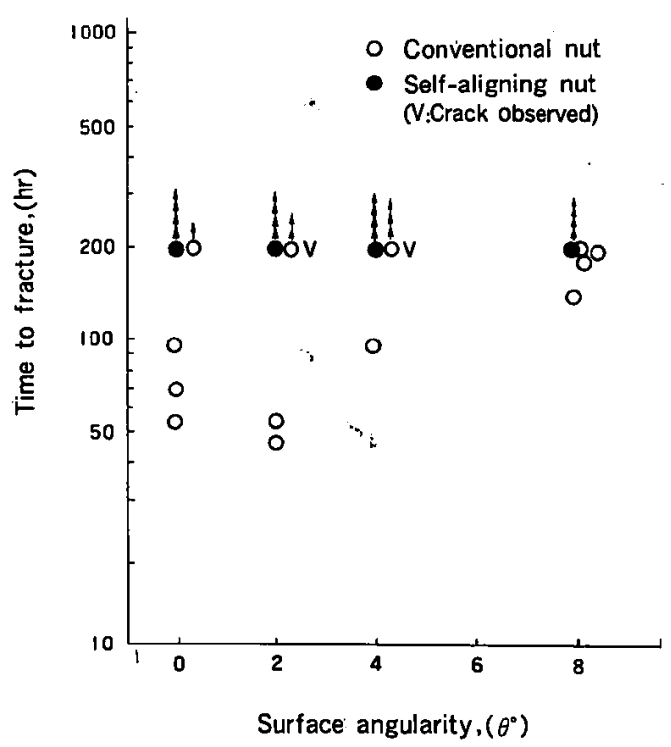

Fig. 12. Effect of self-aligning nuts on the delayed fracture of bolts tightened to wedged plate in $0.1 \mathrm{~N}-\mathrm{HCl}$. 
のくさび角のむのはそれぞれ 4 本とも破断するかクラ ックが検出されている。これにたいし球面座ナットを 使って締付けたるのは，〈さび角 $0 \sim 8^{\circ}$ 全範囲にわ たって一本の破断も認められずきわめて良い成績を示 している。なお破断時間を比較した場合，くさび角 $4^{\circ}, 8^{\circ}$ のむのの方が $0^{\circ}, 2^{\circ}$ のむのより長寿命とな っているが，高くさび角楴付では高応力側で発生した クラックが断面の低応力側に進さにつれ伝播速度が鈍 るためと考えられる。

以上の結果から, 球面座ナット・ワッシャーによる 曲け応力の楥和は遅れ破壊寿命改善にきわめて有効で あるといえる。

摩擦接合ボルトは，首下座面およびナット座面の傾 きがそれぞれ $1^{\circ}$ まで許容されていること，ボルト穴 とボルト径にクリヤランスがあるので主板と点接板と が食違った場合にボルトが斜めに洁入されることがあ るなど, 奉際の施行にあたっては, $0^{\circ} \sim 3^{\circ}$ 程度のく さび角を持って楴付られる可能性が十分ある。このよ うな場合に球面座ナット・ワッジーーの効果はきわめ て大きいものと考党られる。

\section{-4. ま と め}

摩擦接合用高力ボルトの遅れ破壊強度改善の試みと して，ボルト各部の応力集中を緩和するような二，三 の方法について夷験的に検討したところ，次の結論か 得られた。

（1）ねじ切上りの不完全ねじ部は，この部分を有効径 まで除去することによって遅れ破壊寿命を延ばす
ことが可能である。

（2）ねじビッキは，谷底断面積の大きい細目ねじの方 が並目ねじより傹れているが，太径ボルトでは小 径ボルトに比べ効果が小さい。

（3）放じ谷底半径を大きくすると遅れ破壊強度の改善 が著しい。

（4）ボルト首下の隅肉半径は大きい方が望ましい。

(5) 球面座ナット・ワッシャーの採用は, ボルト締付 時に発生する曲げ応力綏和に有効であり逮れ破壤 寿命を延ばす。

上記(1)〜 (5)は，一定鋼種，一定促進環境下での遅れ 破壊特性について得られた結果なので，他の鋼種ある いは異なった環境下での遅れ破壊強度特性の改善にそ のまま適用できるか否かはさらに検討の要があるが， 簡単な形状変更でかなりの効果が期待できるので, 今 後の応用を考えてりきたい。

\section{（文献）}

1）安部：ねじと技術 7 (1966) 5, 19

2) H.H.Johnson, J.G.Morlet and A.R. Troiano: Trans. of The Metallurgical Society of AIME. 212 (1958) 8, 528

3）山本，藤田：神宁製銅技報 18 (1968）3，93

4）安部：ねしと技術 7 (1966) 2, 4

5) M I L-S 8879

6) N.P.Chironis : Product Engineering, Nov. 14, 1960

7）松山：鉄道技術研究所速報 No. 70-119, (1970)

8) R. Ollis : Machine Design June 21, 1962 